\title{
Comparing Between Production Scheduling Methods to Achieve Efficient Resource Utilization
}

\author{
Ellysa Nursanti ${ }^{1}$, Sibut ${ }^{2}$, Sudharsan Jayabalan ${ }^{3}$, Fourry Handoko ${ }^{1}$, and Nindya Oktarina ${ }^{1}$ \\ ${ }^{1}$ Department of Industrial Engineering, Institut Teknologi Nasional(ITN), Malang \\ ${ }^{2}$ Department of Mechanical Engineering, Institut Teknologi Nasional(ITN), Malang \\ ${ }^{3}$ Department of Electronics and Communication Engineering, Gokaraju Rangaraju Institute of Engineering and \\ Technology, Hyderabad, India \\ e-mail: ellysa.nursanti@lecturer.itn.ac.id
}

\begin{abstract}
High competition among industries nowadays, requires companies to improve their production services. The speed of production service time, with excellent quality, becomes part of the company's competitive advantage. This study aims to compare several production scheduling methods which are commonly used, so that efficient resource utilization can be obtained. Production Scheduling Methods such as Make to Order, Dannenbring, Branch and Bound, Nawaz Enscore and Ham and Campbell Dudeck Smith were compared using one case of tire retreading production. There were two jobs: tire retreading for truck and bus. Each job, assigned to ten workstations following its production steps. The results were obtained that Dannenbring and Campbell Dudeck Smith gave the same best results with the smallest makespan value, equivalent to $48 \%$ efficiency.
\end{abstract}

Keywords-Branch and Bound, Campbell Dudeck Smith, Dannenbring, Nawaz Enscore and Ham, Production.

\section{INTRODUCTION}

$\mathrm{O}^{\mathrm{s}}$ $\mathrm{NE}$ of the competitive advantage that must be owned by companies, especially those engaged in services, in addition to quality at this time is the speed of service to meet consumer demand and expectation. The speed of service to meet consumer demand is dependently influenced by the length of production time. Production time is highly dependent on the type of product variation produced, the flow of production process, production machinery and equipment facilities, availability of materials and labor with good skills and the selection of production scheduling methods.

There are many production scheduling methods, such as Make to Order [1], [2], Branch and Bound [3], [4], [5] Campbell Dudeck Smith [6], [7], Dannenbring [8], [9],Nawaz Enscore and Ham (NEH) [10], [6], [11], Integer Programming and Heuristic Algorithm such as Genetic Algorithm [12], [13], Tabu Search [4], and Particle Swarm Optimization [11] or any combination of them [4], [6], [11], [7]. However, there is no study yet, which comparing those methods. Which method is appropriate in what condition. In another side, many small companies still use traditional approach to manage their production scheduling [14]. They commonly prioritize production activities for product type which has higher difficulty level or longer completion time. This is good on one side, the company can concentrate focusing on products which are more difficult or take longer production time, so that the next job will be easy and faster to be accomplished. However, this consideration is not entirely wise since the work of difficult and longer firstly done; there will be an imbalance in the production line; there will be a queue in production; consumer demand will be served longer and this will be a boomerang for the survival of its company in the future. Considering those condition, this study was conducted with theaim of comparing production scheduling makespan result by using five methods (actual make to order, Dannenbring, Branch and Bound, Nawaz Enscore and Ham and Campbell Dudeck Smith) and obtaining the best efficiency result.

\section{DESCRIPTION SYSTEM}

This research takes a case study on tire retreading production process where they have two types of tires i.e. Truck tires (Job 1) and Bus tires (Job 2). This company through conventional make to order method, did the truck tire retreading first (Job 1) because this product type was known to be more difficult and required relatively longer time to produced so it tooks as precedence to other (Figure 1) Each tire retreading job has 10 stages of production activities. This can be seen in Figure 1. This condition raises the queue of the production process due to increasing makespan. Consumers have to wait longer to have their orders to be completed. Many orders can not be served. Following in Table $1 \mathrm{e}$ number of Consumer order request (demand) and number of production output of Truck and Bus Tires in the last 4 months. Next in Table 2, it can be seen the production time required for each job.

\section{METHODOLOGY}

In this study, the lowest makespan criteria is used to get the best scheduling method and result in efficiency. The research stages starts from the calculation of the completion time to obtain current makespan. Completion time is obtained from standard time calculations, data uniformity test and data adequacy test. Then the four methods compared (Dannenbring, Branch and Bound, Namaz Enscore and Ham and The Campbell Dudeck and Smith) are used to obtain lowest makespan which also means highest efficiency. 
Table 1.

Demand and production

\begin{tabular}{cccccc}
\hline \hline \multirow{2}{*}{ No } & \multirow{2}{*}{ Month } & \multicolumn{2}{c}{ Demand (Unit) } & \multicolumn{2}{c}{ Production (Unit) } \\
& & Truck & Bus & Truck & Bus \\
\hline 1 & July ,19 & 120 & 115 & 110 & 119 \\
2 & August ,19 & 115 & 110 & 109 & 117 \\
3 & September ,19 & 110 & 115 & 118 & 110 \\
4 & October ,19 & 115 & 120 & 110 & 111 \\
\hline \hline
\end{tabular}

Table 2 .

Production duration time per workstation per job

\begin{tabular}{clccc}
\multicolumn{6}{c}{ Production duration time per workstation per job } \\
\hline \hline \multirow{2}{*}{ No } & Work stations & \multicolumn{3}{c}{ Duration (time) } \\
& & Truck & Bus & Total Time \\
\hline \multirow{2}{*}{1} & Arrival and Tire & 15 & 15 & 30 \\
& Checking & 37 & 33 & 70 \\
2 & Tire Cleaning & 20 & 20 & 40 \\
3 & Tire Grinding & 35 & 31 & 66 \\
4 & Fur Removal & 24 & 23 & 47 \\
5 & Glueing & 30 & 32 & 62 \\
6 & Rubber Mounting & 47 & 38 & 85 \\
7 & Edge Rubber Mounting & 26 & 24 & 50 \\
8 & Tire Range Mounting & 180 & 181 & 361 \\
9 & Heating Process & 10 & 11 & 21 \\
10 & Final Inspection & 424 & 408 & 832 \\
\hline \hline
\end{tabular}

Table 3 .

Job scheduling and makespan

\begin{tabular}{ccc}
\hline \hline Scheduling Methods & Job Order & $\begin{array}{c}\text { Makespan } \\
\text { (minutes) }\end{array}$ \\
\hline Make To Order & $1-2$ & 832 \\
Dannenbring & $2-1$ & 432 \\
Branch And Bound & $2-1$ & 587 \\
Nawaz Enscore And Ham & $2-1$ & 572 \\
Campbell Dudeck Smith & $2-1$ & 432 \\
\hline \hline
\end{tabular}

\section{A. Standard Time}

\section{1) Cycle Time (WS)}

Cycle time is the time taken to complete the production of one unit from beginning to end as given in eq. 1 as follow,

$$
W S=\Sigma \frac{X_{i}}{N}
$$

Where $\mathrm{Xi}=$ estimated completion time, and $N=$ number of observations made.

\section{2) Normal Time $(W N)$}

Normal time is working time that has taken into account the adjustment factor, that is, the average cycle time multiplied by the adjustment factor as seen in eq. 2 .

$$
\begin{gathered}
P_{i}=\text { Rating Factor } \\
P=1+P_{i} \\
W N=W S \times P
\end{gathered}
$$

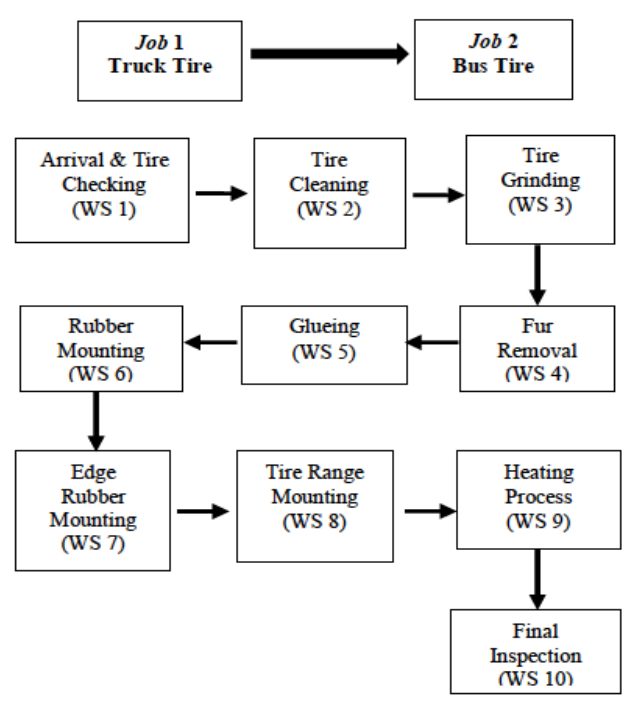

Figure 1. The Process Flow in Job \& Work Stations (WS) of Each Job.

Where WS = cycle time; $\mathrm{P}=$ adjustment factor $; \mathrm{P}=1$ when working time classified in FAIR ; $\mathrm{P}<1$ when working time classified in too SLOW and $\mathrm{P}>1$ when working time classified in too FAST.

3) Standard Time (WB)

Standard time is the actual time of the operator uses to produce one unit of product type concerning normal time and allowance, as given in eq. 3 as follow,

$$
W B=W N \times \frac{100}{100-\text { allowance }}
$$

\section{B. Data Uniformity Test}

Control limits are derived from data that is the limit by which to determine the data are uniform or not. The data is uniform when the average is between the controls and if there is data beyond the controls then the data is not uniform. In determining the limits of control may use these following eq. from 4 to 9 .

1) The average ( $x$ )

$$
\overline{\bar{x}}=\frac{\sum_{i=1}^{k} \bar{x}_{i}}{K}
$$

2) Deviation Standard ( $\delta$ )

$\delta=\frac{\sqrt{n \sum_{j=1}^{n-1} X^{2} j-\left(\sum_{j=1}^{n-1} X_{j}\right)^{2}}}{n-1}$

3) Variance $(\delta x)$

$\delta_{\bar{x}}=\frac{\delta}{\sqrt{n}}$

4) By using 95\% confidence level, it is obtained that $Z_{x / z}=1,96$ (from table $\mathrm{Z}$ ) 
5) Upper Control Limit (BKA)

$$
\begin{aligned}
& B K A=\overline{\bar{x}}+2 \delta_{x} \\
& \text { 6) Lower Control Limit (BKB) }
\end{aligned}
$$

$$
B K B=\overline{\bar{x}}-2 \delta_{x}
$$

Where $X j=$ data from $j$ th observation $(\mathrm{j}=1,2,3, \ldots, \mathrm{n}) ; x i=$ the average data of ith group observation; $K=$ number of sub group $; n=$ number of data in each sub group ; $N=$ number of data.

\section{Data Adequacy Test}

Data is adequate sufficient when number of observation data $(N)$ is more than number of data in theory $\left(N^{\prime}\right)$. If $X i=$ the average of observation data in $i t h$ sub group ; $K=$ Number of sub group ; $n=$ number of data in each group; $N=$ number of data, then number of data in theory is given in eq. 9 as follow,

$$
N^{\prime}=\left(\frac{\frac{k}{s} \cdot \sqrt{n \sum_{i=1}^{n} x_{i}^{2}-\left(\sum_{i=1}^{n} x_{i}\right)^{2}}}{\sum_{i=1}^{n} x_{i}}\right)^{2}
$$

\section{Dannenbring Methods}

Dannenbring method schedules work sequence from the fastest to the slowest.

1) Time of process sequence in first machine (ai) as seen in eq. 10

$$
a i=\sum_{j=1}^{m}(m-j+1) \cdot \mid t_{i j}
$$

2) Time of process sequence in second machine (bi) as seen in eq. 11

$$
b i=\sum_{j=1}^{m} i \cdot t_{i j}
$$

Where $m=$ number of machines ; $i=$ job ; $j=$ machines used to process job $1 ; t i j=$ processing time for job $-i$ at machine $j$

\section{E. Branch and Bound Methods}

This method can minimize the production processing time and avoid idle machine time. Scheduling each job is done according to calculation at each lower limit makespan is the smallest value of first iteration.

1) Processing time needed for machine 1 (M1) is given in eq. 12 as follow

$$
M 1=\sum t_{j 1}
$$

2) First lower control limit of machine makespan (b1) is given in eq. 13 as follow

$$
b_{1}=q_{1}+\sum_{j \in T^{\prime}} t_{j 2}+\min _{j \in T^{\prime}}\left\{t_{j 2}+t_{j 3}\right\}
$$

3) Second lower control limit obtained from machine 2 (b2) is given in eq. 14 as follow

$$
b_{2}=q_{2}+\sum_{j \in T^{\prime}} t_{j 3}+\min _{j \in T^{\prime}}\left\{t_{j 3}\right\}
$$

4) Processing time on machine 3 (b3) is given in eq. 15 as follow

$$
b_{3}=q_{1}+\sum_{j \in T^{\prime}} t_{j 3}
$$

5) Lower control limit obtained from maximum value (B) is given in eq. 16 as follow

$$
B=\max \left\{b_{1}, b_{2}, b_{3}\right\}
$$

Where $t_{i}=$ processing time $; q_{1}=$ last completion time on machine 1 among jobs ; $q_{2}=$ last completion time on machine 2 among jobs ; $q_{n}=$ last completion time on machine $\mathrm{n}$ among jobs.

\section{F. Nawaz Enscore and Ham Methods}

The method was developed by Nawaz, Enscore and Ham in 1983. This method is called Incremental Construction Algorithm method. Scheduling using Nawaz, Enscore and Ham method determines working sequence based on SPT approach (Short Processing Time). The order of completion time for each job is sorted from the largest to the smallest using these eq. 17 and 18

$$
\begin{gathered}
C_{i, j}=t_{i, j}+\max \left(C_{i-j}, C_{i, j-1}\right) \\
C_{i, 0}=0 ; C_{0, j}=0
\end{gathered}
$$

Where $C_{i j}=$ completion time of job $i$ on machine $j ; t_{i j}=$ processing time of job $i$ on machine $j$

\section{G. Campbell Dudeck Smith Methods}

Campbell Dudeck Smith method is a method that determines the sequence of product processing based on the time of completion of the process from the smallest to the largest by using eq. 20 as follow,

$$
t_{B_{i, j}}=\frac{W_{B_{i, j}} x Q_{i}}{M_{j} x C_{i j}} ; i, j=1,2,3
$$

Where $W_{B i j}=$ processing time for job ; $Q_{i}=$ number of demand once order on job $i ; M_{j}=$ number of machines at work station $j ; C_{i j}=$ production capacity per machine $j$.

\section{RESULT AND DISCUSSION}

By comparing those four methods with conventional make to order method which is recently used by the company, we come to the result as seen in Table 3. In Table 3, here is the list of makespan for each method ees job order. Next in Table 2 , it can be seen the production time required for each job.

From Table 3, it is clearly seen that both methods of Dannenbring and Campbell Dudeck Smith, delivered same result in makespan 432 minutes. It is 400 minutes faster, compared to actual makespan 832 minutes, so that this result equal to $48.07 \%$ efficiency. Both proposed methods delivered same job order start from job 2 (Bus tire retreading), followed by job 1 (truck tire retreading), contrast to actual job order which is job 1 to 2 . This result of job sequence is understandable since job 2 has shorter completion time than job 1. 
Scheduling job sequence, not only need to consider time period, but also has to control manufacturing cost [15], lean manufacturing to eliminate the waste [16], and maintenance scheduling [17], so that the company may optimize its production capacity [18]. The job sequences need to be evaluated periodically using the concept of continuous improvement, thus it may result in green industrial system [19], [20].

\section{CONCLUSIONS}

After comparing all those methods, we come to conclude that Dannenbring method and Campbell Dudeck Smith (CDS) method delivered the same best result i.e. shortest makespan. Both methods decrease makespan from 832 minutes to 432 minutes, equal to $48 \%$ efficiency, with the work sequence: Job 2 then Job 1, bus tire retreading then followed by truck one. For further research, it needs to do more exploration on those methods characteristics, in what condition each method is performing well.

\section{REFERENCES}

[1] H. Tannady, "Modifikasi mekanisme penentuan penjadwalan job pada metode dannenbring," no. 2, pp. 1-9, 2013. [in Bahasa]

[2] N. I. Lesmana, "Penjadwalan Produksi Untuk Meminimalkan Waktu Produksi Dengan Menggunakan Metode Branch And Bound," vol. 17 , no. 1, pp. 42-50, 2016. [in Bahasa]

[3] G. Mohammadi, "Multi-objective flow shop production scheduling via robust genetic algorithms optimization technique," vol. 2, no. 1, pp. 1-8, 2015.

[4] C. E. Nugraheni and L. Abednego, "On the Development of Hyper Heuristics Based Framework for Scheduling Problems in Textile Industry," vol. 6, no. 5, pp. 272-276, 2016.

[5] S. Talapatra, "Application of Branch and Bound algorithm for solving flow shop scheduling problem comparing it with Tabu search algorithm," no. December 2014, 2018.

[6] M. G. Wolde, E. Berhan, and K. Jilcha, "Production improvement with flow shop scheduling heuristics in Household utensils manufacturing company," Cogent Eng., vol. 13, pp. 1-11, 2018.

[7] M. I. Takano and M. S. Nagano, "A branch-and-bound method to minimize the makespan in a permutation flow shop with blocking and setup times makespan in a permutation flow shop with blocking," Cogent Eng., vol. 52, no. 1, pp. 1-16, 2017.

[8] W. Liu, Y. Jin, and M. Price, "International Journal of Production Economics A new improved NEH heuristic for permutation fl owshop scheduling problems,” Int. J. Prod. Econ., vol. 193, no. June 2016, pp. 21-30, 2017.

[9] L. Gozali, V. Kurniawan, S. Ramadhani, "Design of Job Scheduling System and Software for Packaging Process Desi $\mathrm{g} n$ of Job Scheduling System and Software for Packaging Process with SPT EDD , LPT , CDS and NEH algorithm at PT .," I. O. P. C. Series and

[10] M. Science, pp. 1-8, 2019. Z. Yang, Z. Ma, and S. Wu, "Automation in Construction Optimized $\mathrm{fl}$ owshop scheduling of multiple production lines for precast production," Autom. Constr., vol. 72, pp. 321-329, 2016.

[11] Y. Muharni, "Production scheduling of bar mill using the combination of particle swarm optimization and Nawaz enscore ham for minimizing makespan in steel company Production Scheduling of Bar Mill Using The Combination of Particle Swarm Optimization and Nawaz Enscore Ham for Minimizing Makespan in Steel Company,' vol. 030006, 2019.

[12] W. T. W. K. Method, C. Dudek, and S. Cds, "Production Scheduling to Minimize Makespan using Sequencing Total Production Scheduling to Minimize Makespan using Sequencing Total Work ( TWK ) Method and Campbell Dudek Smith (CDS) Algorithm,'2019.

[13] U. Rahmani, E. R. Wulan, and A. F. Huda, "Scheduling of Flowshop Type Production with Dannenbring Method to Obtain Optimal Results with Observing Waiting Time and Weight of Jobs," vol. 127, no. April, pp. 212-224, 2019.

[14] F. Handoko, E. Nursanti, D. Harmanto, "The Role of Tacit and
Codified Knowledge Within Technology Transfer Program on Technology Adaptation", ARPN Journal of Engineering and Applied Sciences 11 (8), pp. 5275-5282, 2016.

[15] H. Widyantoro, F. Handoko, E. Nursanti, "Pengendalian Biaya Manufaktur Berbasis Environment Oriented Cost Management (EOCM)”, Prosiding SENIATI, pp. C.55-C.59. 2016. [in Bahasa]

[16] C. Kusbiantoro, E. Nursanti, "Penerapan Lean Manufacturing untuk Mengidentifikasi dan Menurunkan Waste (Studi Kasus CV Tanara Textile)", Jurnal Teknologi dan Manajemen Industri 5, pp. 1-7, 2019. [in Bahasa]

[17] E. Nursanti, S. Avief, Sibut, M. Kertaningtyas, "Maintenance Capacity Planning, Efisiensi dan Produktivitas", CV. Dream Litera Buana, 2019. [in Bahasa]

[18] E. Nursanti, R.I. Purnama, IB. Suardika, "Optimasi Kapasitas Produksi untuk Mendapatkan Keuntungan Maksimum dengan Linear Programming”, Media Ilimiah Teknik Industri 14, pp. 61-68, 2015. [in Bahasa]

[19] F. Handoko, E. Nursanti, S. Sutriyono, "Aplikasi Pendekatan Perbaikan Terus Menerus guna Mencapai Green Industrial System yang berkelanjutan”, Prosiding SENATEK 1 (A), pp. 866-870, 2015. [in Bahasa]

[20] F. Handoko, E. Nursanti, G. Gatot., L. Mulyadi, J. Hutabarat, K. Kustamar, "Green Industrial System in Indonesia", Journal of Telecommunication, Electronic and Computer Engineering, pp. 1-7, 2018. 